\title{
Music Education and Muslims
}

\author{
Diana Harris \\ Stoke on Trent, UK and Sterling, USA: \\ Trentham Books, 2006. 149 pages.
}

Diana Harris presents her research on teaching music to Muslim students in the United Kingdom. She argues that music educators have to take into account that music is a sensitive issue for many Muslims. The fact that music education is compulsory for British pupils until the age of fourteen presents an ethical dilemma for those who, for religious reasons, do not feel comfortable participating in music classes. With this book, the author intends to help 
state schoolteachers understand the history and position of music in Islam and help teachers in state and independent Islamic schools provide music classes that their students might find more acceptable.

Harris has drawn upon her extensive experience as a music educator in the United Kingdom at schools where the pupils have been predominantly Muslim. Her other sources include interviews conducted between 19992005; participant-observation fieldwork undertaken at schools in the United Kingdom, Pakistan, Egypt, and Turkey; and scholarly sources concerning music and Islam. Harris stresses that she has tried to approach this topic as delicately as possible, and that in her capacity as a music teacher, she would never force her pupils to participate in activities that run counter to their personal beliefs. How the musical components of the national curriculum (performing, composing, listening, and appraising) are to be achieved depends upon the individual teacher, who can, therefore, tailor classes to the needs of specific pupils.

The book's organization reflects the various methods with which Harris has researched her topic. Following the "Introduction," in which she states the research problem, the second chapter outlines the bibliographic material on music and Islam. Here, she provides a general introduction to Islam for music educators, citing scholarly opinions of the ahadith, articles by Lois Ibsen al-Faruqi on music and the Shari ah, and the proceedings of two conferences on music and Muslims in United Kingdom schools. The third chapter includes extracts from her interviews of Muslim schoolteachers, scholars, imams, and musicians about Islam and music, creativity and professional musicians, and emotion and spirituality. Both chapters reveal the variety of opinions existing among Muslims about the permissibility of music.

In the fourth chapter, Harris discusses music education in Pakistan, Egypt, and Turkey, where she briefly conducted ethnographic fieldwork. She also summarizes the work of scholars who have researched music education for Muslim students in the United States, Canada, Finland, and Malaysia. Chapter 5 is a case study of a Pakistani family "split between Pakistan and England" (p. 81). Although there are a few quotes from family members, the chapter's text is primarily drawn from her field notes, which she wants her audience to read as a diary.

Chapter 6 is a case study of Castle Community College, where Harris conducted interviews and was a participant-observer during autumn 1999. In the next chapter, she cites two initiatives to promote music for Muslims in schools. The first, undertaken by Harris herself, took place in an independent Islamic school wishing to achieve Voluntary Aided status. During 2004-05 she interviewed participants, taught music classes, and taught teachers how 
to teach music classes themselves. The second initiative, led by Robert Bunting and other specialists in Birmingham, sought to introduce Islamic music and culture into state schools with a high proportion of Muslim students.

These two chapters, combined with the last chapter, are the strongest because they are rooted in the author's extensive experience in the United Kingdom and are the most relevant to her research problem. The fourth and fifth chapters, discussing her fieldwork in Pakistan, Egypt, and Turkey, detract from the study's focus. While it makes sense to relate the author's research in the United Kingdom to music education in other Islamic and diasporic communities, her research lacks depth. The book's great weaknesses are thus found in these sections, where her tone almost resembles that of an Orientalist travelogue. Throughout the book, the writing and the editing could be improved, particularly so as to polish transitions between sections of the text. Editors publishing the book outside of the United Kingdom may also want to provide further explanations about the British school system.

In the final and most effective chapter, Harris offers practical suggestions for music educators teaching Muslim pupils. She recommends that all state teachers - not just music teachers - need to know more about Islam. She advises educators to choose musical examples carefully, particularly during Ramadan, when many parents and students protest practicing music. She also suggests that if the idea of performing music is offensive to some students, teachers might integrate it into other subjects or utilize activities involving singing and computers, rather than musical instruments. After talking with many parents and students, Harris argues that there is a "good case" for teaching music in single-sex classes, especially after puberty (p. 136). She further suggests including music from Islamic cultures in a classroom setting and utilizing Islamic poetry for composition modules. To this end, she provides a list of resources for teachers in the appendix. Lastly, Harris proposes inviting parents into the schools to see what the teachers actually do in music classes.

This book is not the best introduction for music educators to the issues surrounding music and Islam, because the author does not differentiate clearly between religion and culture. Nor is it an extensive study of music education in Islamic countries. Yet overall, Harris presents a strong case for the relevance of her topic and provides helpful advice for music teachers struggling to deal with these issues in a sensitive manner. The book is a useful tool for music educators and administrators in multicultural schools. It might also be appreciated by scholars of Muslim identities in the United Kingdom and other western countries and by scholars interested in questions surrounding music, gender, and Islam. Perhaps its greatest strength is the 
inclusion of direct quotes from the students, parents, and teachers invested in this matter - a valuable resource for anyone wishing to know more about certain Muslims' attitudes toward music.

Alyson E. Jones

Ph.D. Candidate, Musicology University of Michigan, Ann Arbor 